\title{
小児の静脈カニューレサイズと水分バランス
}

\author{
九州厚生年金病院 中央検查室 \\ 八坂文一浜本英治荒井俊一 \\ 同 心臟外科
}

瀬 瀬顯上野安孝

I 、はじめに

近年の小児の心臓手術は手技の確立，人工心肺 の性能の向上により，低年齢化の傾向にある。成 人と違い小児では人工心肺を操作するうえにおい て種々の特殊性がある。特に体外循環中の水分心゙ ランス維持は手術成績を左右する重要な因子之思 われる。適切な脱血カニューレの選択は水分バラ ンス維持に特に寄与するむのと思われる。当施設 でおこなった体重 $4 \mathrm{~kg}$ 未満の乳児体外循環症例に ついて, 脱血カニューレの選択の変遷之手術中の 水分バランスを検討したので, 若干の考察を加え 報告する。

\section{II 。対象と方法}

当施設で1986年 1 月から1991年12月までに行っ た小児体外循環（表 1）のうち, 特们体重 $4 \mathrm{~kg}$ 以 下の症例66例を脱血カニューレの組み合わせによ り, $12 / 14 \mathrm{Fr}, 14 / 16 \mathrm{Fr}, 16 / 18 \mathrm{Fr}$ の3群に分 けた（表 2 ）。各群で体外循環中の水分バランス を比較検討した。

体外循環中の水分バランスの值は人工心肺回路 の残血液量測定が不正確なため, また, 手術終了 時の体重測定が不可能なため測定できない。そて で手術翌日の I C Uでの体重測定値と，それまで の I C Uでの水分バランスから逆算して手術直後 の術後の術後体重とし, 手術日の朝測定した術前 体重之の差より体重增加率を求め, 水分バランス の指標とした。当院で小児の開心術を開始した頃 は, 最小の脱血カニューレは $18 \mathrm{Fr}$ までしか使用 しなかったが, その後徐々に, $18 \mathrm{Fr}$ 以下のカ二 ューレも使用するようになり，現在使用している

\begin{tabular}{lr}
\multicolumn{1}{c}{$\begin{array}{c}\text { 表 1 } \\
\text { 4kg以下の症例 } \\
(' 86 \sim ' 91)\end{array}$} \\
\hline VSD & 29 \\
TAPVC & 13 \\
TGA & 12 \\
PS & 2 \\
TOF & 2 \\
VSD·ASD & 1 \\
PS·IVS & 1 \\
IAA·A-P Window & 1 \\
PA·IVS & 1 \\
PAPVC & 1 \\
ASD & 1 \\
Truncus & 1 \\
HLHS & 1 \\
\hline \multicolumn{1}{c}{ 計 } & 66 \\
\hline
\end{tabular}

表 2 カニューレサイズ別症例

\begin{tabular}{|c|c|c|c|}
\hline & $12 / 14 \mathrm{Fr}$ & $14 / 16 \mathrm{Fr}$ & $16 / 18 \mathrm{Fr}$ \\
\hline 年齢（ヶ月） & $2.17 \pm 1.8$ & $1.96 \pm 1.5$ & $2.0 \pm 1.5$ \\
\hline 体重（g） & $3144 \pm 543$ & $3296 \pm 435$ & $3406 \pm 428$ \\
\hline 大動脈遮断時間（分） & $72 \pm 37$ & $73 \pm 41$ & $73 \pm 37$ \\
\hline 体外话環時間（分） & $112 \pm 49$ & $114 \pm 55$ & $114 \pm 49$ \\
\hline
\end{tabular}

脱血カニューレは, $12 \mathrm{Fr}, 14 \mathrm{Fr}, 16 \mathrm{Fr}$ のスト レートカニューレと直角カニューレあ使用してい る。

体外循環は，中等度低体温（直腸温 $26^{\circ} \mathrm{C} \sim 28^{\circ} \mathrm{C}$ ) 高灌流量（灌流指数 $2.5 \sim 3.0 \mathrm{l} / \mathrm{m}^{2} / \mathrm{min}$ ) 法で 全症例行った。人工心肺の充塓液は最初の数例を

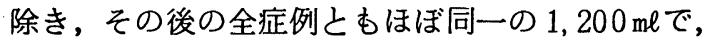
濃厚赤血球とプラズマのみの充填液を使用してい 


\section{表 3 人工肺克统洨粗成衰}

\begin{tabular}{|c|c|c|c|}
\hline \multirow{2}{*}{\multicolumn{2}{|c|}{$\begin{array}{l}\text { Packed red cell } \\
\text { Plasmanate }\end{array}$}} & 520 & $\mathrm{ml}$ \\
\hline & & 500 & $\mathbf{m l}$ \\
\hline \multicolumn{2}{|c|}{$20 \%$ Albumin } & 60 & ml \\
\hline \multicolumn{2}{|l|}{$5 \%$ Glucose } & 50 & $\mathrm{ml}$ \\
\hline \multicolumn{2}{|l|}{ Mannitol } & 2.5 & $\mathrm{ml} / \mathbf{k g}$ \\
\hline \multicolumn{2}{|l|}{ Moylon } & 40 & $\mathrm{ml}$ \\
\hline \multicolumn{2}{|c|}{ Methylprednisolon } & 30 & $\mathrm{mg} / \mathrm{kg}$ \\
\hline \multicolumn{2}{|l|}{ Furosemide } & 10 & $\mathrm{mg}$ \\
\hline \multicolumn{2}{|l|}{ Heparin } & 30 & $\mathrm{mg} / \mathrm{l}$ \\
\hline \multicolumn{2}{|l|}{ Total } & \multicolumn{2}{|l|}{1200} \\
\hline $\mathrm{Na}^{+}$ & 146 & \multicolumn{2}{|c|}{$\mathrm{mEq} / \mathrm{I}$} \\
\hline $\mathrm{K}^{+}$ & 3.6 & \multicolumn{2}{|c|}{$\mathrm{mEq} / \mathrm{I}$} \\
\hline $\mathrm{Ca}^{\#}$ & 0.01 & \multicolumn{2}{|c|}{$\mathrm{mmol} / \mathrm{L}$} \\
\hline $\mathrm{Ht}$ & 23.4 & \multicolumn{2}{|l|}{$\%$} \\
\hline TP & 5.9 & \multicolumn{2}{|l|}{$\theta / d l$} \\
\hline Osm & 290 & \multicolumn{2}{|c|}{ mosm $/ L$} \\
\hline
\end{tabular}

了(表 3 )。

また，心筋保镜液は，最初から同一の組成のク リスタル液を，使用している。

\section{III. 䠜 果}

平均月数 2.1 ケ月 \pm 1.5 个月, 平均体重 $3278 \pm$ $506 \mathrm{~g}$ で, 体重增加率は, $12 / 14 \mathrm{Fr}$ で $1.54 \pm 2.87$ \%, 14/16Frで $1.97 \pm 3.54 \%, 16 / 18 \mathrm{Fr}$ で $2.39 \pm$ 4.18\%と低值であった（表4）。三群の間では， 有意な差はなかったが，カニューレのサイズが太”。 いほど，水分過多になる傾向を認めた（図 1）。

\section{IV. 考 裹}

体外循環中の水分バランスの維持は術後管理や, 手術成績に影䱥を及ぼす重要な日子であると思わ れる。当院では，新生児，乳児に対して一貫して

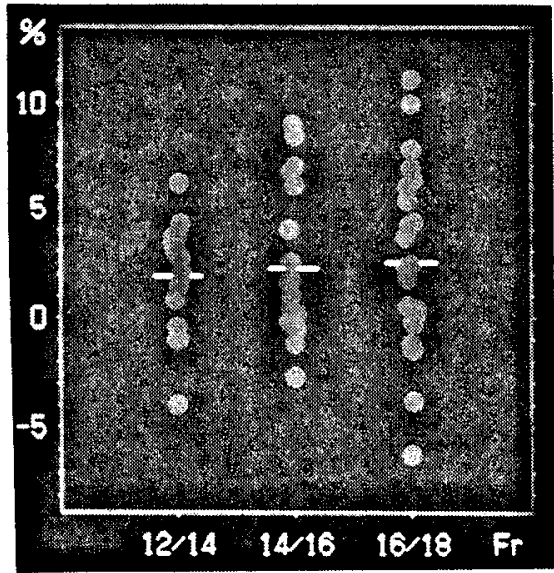

四1カニューレサイスによる水分バランス

高流量中等低体温体外循㻴を行ってきたが，最近， 捚入しやすく，静脈壁との間に余裕があてるよう に，従来の16/18F r より細い脱血管を使用してみ た。脱血管が細くなることにより十分な脱血量が 得られるか否かが㫫念されたが，12/14Frの力二 ニーレで $2.5 \sim 3.0 \mathrm{\ell} / \mathrm{m}^{2} / \mathrm{min}$ の流量を得ること ができた。しかも，以前使用していた16/18Frに 比べ水分バランスはより良好に維持できる。太い カニューレでは静脈壁の coll apse 現象をひきお こし，かえって脱血を墨くしていたと思われる。

\section{V. 知 語}

適切な脱血カニューレの選択，位置の調節を撅 密に行えば，低体重児といえども，過剩な水分負 荷を行うことなく，通常の高流量体外循環を行う ことが可能であった。

$4 \mathrm{~kg}$ 以下の小児の体外循環では，むしろ細い脱 血カニューレのほうが, 高流量を得つつ, 良好な 水分バランスを維持できた。

衰 4 莠中水分バランス（術直後体重增加率）

\begin{tabular}{ccc}
\hline $12 / 14 \mathrm{Fr}$ & $14 / 16 \mathrm{Fr}$ & $16 / 18 \mathrm{Fr}$ \\
\hline $1.54 \pm 2.87 \%$ & $1.97 \pm 3.54 \%$ & $2.39 \pm 4.18 \%$ \\
\hline $\mathrm{NS}$ & $\mathrm{NS}$ \\
\hline
\end{tabular}


参考 文 献

1）八坂文一, 浜本英治, 荒井俊一, 他: 小児体外循 環時に抢ける水分バランスの検討。体外循環技術, 18(2)； 48-51, 1992 。

2 ) 瀬瀬 顕, 上野安孝, 䕎木元友, 他: 中程度低体 温高流体外循環法と低量 $\mathrm{C}^{++}$濃度血充填, 高 $\mathrm{Na}^{+}$,
低 $\mathrm{Ca}^{++}$晶質心筋保護液。日胸外誌, $40(5) ； 681-$ $682,1992$.

3 ) 阿部俊雄, 編 :「人工心肺」理論と実際。

4）横田通夫, 曲 人伸, 水原寿夫, 他：新生児, 乳 児期早期 ( 3 ケ月未満) 開心術の補助手段。人工藏 器学会セミナー雑誌, $123-143,1991$. 